Slatkine (in Geneva) also has some law titles, for example Pasquier's L'Interpretation des Institutes de Justinian (Paris, 1847). Of course, Duchemin carries a number of reprints of particular significance for French legal history. The back run of Revue Trimestrielle de Droit Civil (Vols. 1-66) was jointly reprinted by Duchemin and Verlag Detlev Auvermann $\mathrm{KG}$.

Zentralantiquariat der DDR in the German Democratic Republic also publishes a Reprint Catalog which offers a number of legal items. Keip Verlag K.G. in Frankfurt has just released their legal reprint catalog of only German language materials.

Xerox University Microfilms has a growing number of items available in microformat and copyflow. A number of very interesting manuscript offerings in microfiche is being distributed through Esselete Video in New York, representing microfiche of Russian and Soviet books done by INTERDOK (Interdocumentation Company) of Zug, Switzerland. INTERDOK has also reprinted numerous English legal manuscripts from Harvard, Lincoln's Inn, the Bodleian Library, Gray's Inn, and Yale. Professional Books has reprinted British maritime cases, the Law Commission working papers, and numerous other items.

In the United States, we are familiar with the Hein and Arno Press reprints in American Legal History, as well as the notable Rothman Reprints which include, inter alia, The Continental Legal History Series.

Greenwood Press has also reprinted some interesting items, notably the 1951 edition of Vyshinskii's The Laze of the Soviet State.

The Hyperion Press in Westport, Connecticut, has been reprinting a number of very interesting items, including English translations of the works of Bartolus, von Jhering, and Savigny.

I would like very much to hear from anyone who has additional information on reprints of European legal materials either in hard copy or microform.

David A. Combe

Tulane University

\title{
COMPUTERIZED LEGAL RESEARCH IN AUSTRALIA
}

The Commonwealth Parliamentary Library has recently announced that the Attorney-General's legal information retrieval system SCALE (Statutes and Cases-Automated Legal Inquiry) is now available for use to members of the Commonwealth Parliament. SCALE offers the means to search the full texts of federal statutes and to retrieve information from such statutes in any combination of words.

Information about SCALE and the related computer assisted transcription system (CAT) is contained in the second annual report (197980) of the Commonwealth Attorney-General's Department (Canberra: 
Australian Government Printing Service, 1980). The SCALE data bases now consist of the 1973 Consolidation of the Commonwealth Statutes, and subsequent annual legislation, the texts of the Australian Capital Territory Ordinances, and the Commonwealth Law Reports, vols. 128-138.

Australian Laze Librarians' Group Nezwsletter, No. 40

(October 1980), p. 5

\section{COMPUTERIZED LEGAL RESEARCH IN EUROPE}

Trade journals are reporting the development of a computerized legal research service by two British companies. Called Eurolex, the system is designed to retrieve information from the huge volume of case law, legislation and regulatory material originating in Europe, both national and European Community. BOC Datasolve limited a subsidiary of BOC International, Ltd., is providing the computer hardware and software, as well as the telecommunications facilities through which the service will be, in the jargon of the trade, accessed. The data base itself is being developed by European Law Centre Limited in London.

In the meantime Mead Data Central, producer of the LEXIS computerized legal information service in the United States, is expanding its data base to include English law. In conjunction with Butterworth, a major English law publisher, it is creating a data base for English legislation and case law which will be made available to all LEXIS subscribers on both sides of the Atlantic. Mead Data Central is also conducting negotiations for a similar service in Australia.

\section{FORD FOUNDATION GRANTS FOR LEGAL AND HUMAN RIGHTS WORK}

The Ford Foundation traditionally makes grants on a selective basis for training, research and publication projects which appear to promote the international advancement of law and justice. Readers may be interested in some recent grants of the Foundation in two intensively debated and publicized areas: human rights and the development of new legal systems.

\section{Human Rights}

Lawasia Research Institute (Australia), U.S. $\$ 25,000$, for its recently constituted standing committee on human rights in Asia and the Pacific. 